\title{
Suppressive oligodeoxynucleotides synergistically enhance antiproliferative effects of anticancer drugs in A549 human lung cancer cells
}

\author{
RYOHEI TAKAHASHI ${ }^{1}$, TAKASHI SATO ${ }^{1}$, DENNIS M. KLINMAN ${ }^{2}$, TAKESHI SHIMOSATO ${ }^{3}$, \\ TAKESHI KANEKO ${ }^{1}$ and YOSHIAKI ISHIGATSUBO ${ }^{1}$
}

\author{
${ }^{1}$ Department of Internal Medicine and Clinical Immunology, Yokohama City University Graduate School of Medicine, \\ Yokohama 236-0004, Japan; ${ }^{2}$ Center for Cancer Research, Cancer and Inflammation Program, National Cancer \\ Institute at Frederick, Frederick, MD 21702, USA; ${ }^{3}$ Graduate School of Agriculture, \\ Shinshu University, Nagano 399-4598, Japan
}

Received October 13, 2012; Accepted December 4, 2012

DOI: $10.3892 /$ ijo.2012.1755

\begin{abstract}
Immunosuppressive oligodeoxynucleotides (Sup ODNs) containing repetitive TTAGGG motifs reduce inflammation and, thus, may have an impact on inflammation-related tumor growth. In this study, we found a significant antiproliferative effect of Sup ODNs on the A549 non-small cell lung cancer (NSCLC) cell line compared to those treated with control ODNs $(\mathrm{p}<0.05)$. Sup-ODN-mediated G1 phase cell cycle arrest was achieved via inhibition of Akt and extracellular signal-regulated kinase $1 / 2$ phosphorylation and the $\mathrm{p} 15^{\mathrm{INK} 4 \mathrm{~b}}$ and $\mathrm{p} 27^{\mathrm{KIP} 1} /$ retinoblastoma protein pathway. In addition, Sup ODNs induced apoptosis and enhanced apoptosis when combined with vinorelbine. In a setting similar to clinical use of multidrug chemotherapy for advanced NSCLC, these effects were investigated by using Sup ODNs in combination with conventional anticancer drugs. Sup ODNs had a significant synergistic effect with 5-fluorouracil, vinorelbine, gemcitabine, paclitaxel and irinotecan, with a mean combination index of 0.43-0.78 (<1.0 indicates synergism) in the A549 NSCLC cell
\end{abstract}

Correspondence to: Professor Yoshiaki Ishigatsubo, Department of Internal Medicine and Clinical Immunology, Yokohama City University Graduate School of Medicine, 3-9 Fukuura, Kanazawa-ku, Yokohama, Kanagawa 236-0004, Japan

E-mail: ishigats@med.yokohama-cu.ac.jp

Abbreviations: 5-FU, 5-fluorouracil; 7-AAD, 7-amino-actinomycin D; ATM, ataxia-telangiectasia mutated; BrdU, bromodeoxyuridine; Cdk, cyclin-dependent kinase; CI, combination index; ERK, extracellular signal-regulated kinase; MTT, 3-(4,5-dimethylthiazol-2-yl)-2,5-diphenyltetrazolium bromide; NHBE, normal human bronchial epithelial; NSCLC, non-small cell lung cancer; PARP, poly ADP ribose polymerase; PI, propidium iodide; pRb, retinoblastoma protein; SCLC, small cell lung cancer; Sup ODN, immunosuppressive oligodeoxynucleotide; VNR, vinorelbine ditartrate

Key words: suppressive oligodeoxynucleotides, lung cancer, Akt, extracellular signal-regulated kinase, drug synergism line. In conclusion, our results showed that Sup ODNs have an anticancer effect and increase the sensitivity of NSCLC cells to conventional anticancer drugs by modifying Akt and the extracellular signal-regulated kinase $1 / 2$ pathway. Thus, Sup ODNs may serve as a novel therapeutic strategy for NSCLC patients.

\section{Introduction}

Lung cancer is the leading cause of cancer-related mortality in both men and women worldwide (1). It is mainly classified into small cell lung cancer (SCLC) and non-small cell lung cancer (NSCLC). As compared to NSCLC chemotherapy, SCLC shows a better response towards radiotherapy and chemotherapy. Although the platinum-based doublet chemotherapy is the first-line standard chemotherapy for advanced disease, the response rate of NSCLC is only approximately $30 \%$, resulting in 9 months overall survival (2). The poor prognosis of lung cancer is mainly because of the characteristics of this tumor to metastasize to distant organs early in the course of the disease. These processes are mainly mediated by transmembrane receptors called integrins, which act as the bridge between the cytoskeleton and extracellular matrix proteins, and are essential elements of tumor invasion and metastasis formation (3). Our previous study provided evidence that integrin-linked kinase, integrin $\beta 1$, and the activated form of Akt are mutually associated with poor prognosis in NSCLC patients (4). In addition, it is also known that extracellular signal-regulated kinase (ERK) signaling pathway is aberrantly activated in cancer, in particular by upstream activation by the epidermal growth factor receptor and the Ras small guanosine triphosphatases and then promotes proliferation, cell survival and metastasis $(5,6)$.

Inflammatory processes are associated with the development and/or progression of cancer $(7,8)$. Previous reports have suggested that treatment with anti-inflammatory agents may reduce host susceptibility to cancer development $(7,8)$. Recent studies have shown that immunosuppressive oligodeoxynucleotides (Sup ODNs) containing repetitive TTAGGG motifs prevent inflammation, including arthritis, lupus nephritis, toxic shock, acute silicosis and inflammation-associated oncogenesis (9-16). 
The aim of this study was to examine the effect of Sup ODNs on NSCLC cells. Sup ODNs reduced Akt and ERK1/2 phosphorylation in a dose-dependent manner, leading to cell cycle arrest and apoptosis in A549 NSCLC cell line. Moreover, this anticancer effect of Sup ODNs was amplified synergistically in combination with conventional anticancer drugs, suggesting that Sup ODNs might be clinically important in patients with NSCLC.

\section{Materials and methods}

ODNs and reagents. Phosphorothioate ODNs were purchased from Integrated DNA Technologies (IDT, Coralville, IA, USA). The sequence of Sup ODN was TTAGGGTTAGGGTTAG GGTTAGGG and control ODN was GCTAGATGTTAGCGT. Previous studies have shown that the effect of Sup ODNs was sequence-dependent but not length-dependent and that the length of the control ODNs did not affect activity (16). 5-Fluorouracil (5-FU) was purchased from MP Biomedicals (Irvine, CA, USA). Gemcitabine, paclitaxel, vinorelbine ditartrate (VNR), irinotecan hydrochloride trihydrate, carboplatin and cisplatin were purchased from Wako Pure Chemical Industries (Osaka, Japan).

Cell lines and culture. Non-small cell lung cancer cell line: A549 (p16-null, wild-type p53) cells were purchased from the American Type Culture Collection (Manassas, VA, USA) and maintained in RPMI-1640 medium (Sigma-Aldrich, St. Louis, MO, USA) supplemented with $1 \%$ (v/v) GlutaMAX (Invitrogen, Carlsbad, CA, USA), $1 \%$ (v/v) penicillin-streptomycin (Invitrogen), 10\% (v/v) fetal bovine serum (Equitech-Bio, Ingram, TX, USA). Normal human bronchial epithelial (NHBE) cells were purchased from EIDIA (Tokyo, Japan) and maintained in Airway Epithelial Cell Growth Medium (PromoCell, Heidelberg, Germany). Single-cell suspensions were allowed to attach to the plate over $24 \mathrm{~h}$ in 6- or 96-well plates (Sumitomo, Osaka, Japan). Phosphorothioated ODNs were added to culture $1 \mathrm{~h}$ before administration of anticancer drugs.

Cell viability assays. Anticancer drugs and/or ODN-mediated cytotoxicity was assessed using MTT [3-(4,5-dimethylthiazol2-yl)-2,5-diphenyltetrazolium bromide] assay as previously described (15). Cells were seeded in 96-well plates at a density of 4,000 cells/well and allowed to adhere for $24 \mathrm{~h}$. The cultures were then exposed to anticancer drug with/without Sup ODNs or control ODNs $(0.1,0.3,1,3,10$ and $30 \mu \mathrm{M})$ for $72 \mathrm{~h}$, followed by MTT assay. Briefly, $100 \mu \mathrm{l}$ medium containing MTT (Dojindo Laboratories, Osaka, Japan; $0.5 \mathrm{mg} / \mathrm{ml}$ ) was added to the adherent cells for $2 \mathrm{~h}$. Non-internalized MTT was then washed away and the cells lysed by the addition of $50 \mu \mathrm{l}$ DMSO. This released the MTT internalized by viable cells. MTT concentration was measured colorimetrically and cell viability determined as the $\mathrm{OD}_{570}$ of treated/untreated cultures.

Cell cycle analysis. Adherent cells were incubated with $10 \mu \mathrm{M}$ bromodeoxyuridine (BrdU) for $45 \mathrm{~min}$. Adherent cells were detached with trypsin, washed in PBS and incubated with $20 \mu \mathrm{l}$ anti-BrdU-FITC for $20 \mathrm{~min}$ and with $2.5 \mu \mathrm{l}$ 7-amino-actinomycin D (7-AAD) for 15 min according to the manufacturer's instructions (BrdU Flow Kit; BD Pharmingen, San Diego, CA,
USA). Analysis was performed using a BD FACSCanto II flow cytometer (BD Biosciences, San Jose, CA, USA) and FlowJo v7.6.5 64-bit software (Treestar, Ashland, OR, USA).

Apoptosis analysis. Cells were incubated with/without $3 \mu \mathrm{M}$ Sup ODNs or control ODNs in the presence or absence of $10 \mathrm{nM}$ VNR from 24 to $48 \mathrm{~h}$. Adherent cells were detached with trypsin, washed in PBS and incubated with $10 \mu \mathrm{l} \mathrm{FITC}$ conjugated Annexin V and $5 \mu 1$ propidium iodide (PI) for $15 \mathrm{~min}$ in the dark according to the manufacturer's instructions (MEBCYTO apoptosis kit; Medical and Biological Laboratories, Nagoya, Japan). Analysis was performed using a BD FACSCanto II flow cytometer (BD Biosciences) and FlowJo v7.6.5 64bit software (Treestar).

Western blot analysis. Cells were cultured with Sup ODNs or control ODNs $(0.1,0.3,1,3$ and $10 \mu \mathrm{M})$ for $1,3,6,12,18$ and $24 \mathrm{~h}$, and then lysed in cold buffer containing $137 \mathrm{mM}$ sodium chloride, $20 \mathrm{mM}$ Tris, $1 \mathrm{mM}$ EDTA, $50 \mathrm{mM}$ sodium fluoride, $1 \%$ Triton $\mathrm{X}$, protease inhibitor cocktail and phosphatase inhibitor cocktail (Sigma-Aldrich). Protein concentrations were determined using a BCA Protein Assay kit (Thermo Scientific, Rockford, IL, USA), and $10 \mu \mathrm{g}$ whole cell extract was boiled for $5 \mathrm{~min}$ in sample buffer. The boiled samples were run on $4-12 \%$ gradient SDS-PAGE and transferred onto PVDF membranes. Immunoblots were probed with antibody specific to Akt (pan), phospho-Akt (Ser473), phospho-Akt (Thy308), ERK, phosphor-ERK1/2, cyclin-dependent kinase 4 (Cdk4), Cdk6, cyclin D1, p15 ${ }^{\mathrm{INK} 4 \mathrm{~b}}, \mathrm{p} 27^{\mathrm{KIP} 1}$, p21 (Cell Signaling Technology, Beverly, MA, USA), cyclin E (Invitrogen), Cdk2 (EMD Millipore Corporation, Billerica, MA, USA), p53 and retinoblastoma protein ( $\mathrm{pRb}$ ) (BD Pharmingen), followed by HRP-conjugated secondary antibody (Cell Signaling Technology). Signals were visualized using an enhanced chemiluminescence kit (GE Healthcare, Piscataway, NJ, USA). Blots were reprobed with anti- $\beta$-actin antibody (Santa Cruz Biotechnology, Santa Cruz, CA, USA) to normalize for protein loading.

Statistical analysis. Statistical analyses were performed using GraphPad PRISM, version 5.01 (GraphPad Software, San Diego, CA, USA). Differences between groups were assessed using the t-test. All tests were two-sided; $p$-values of 0.05 were considered significant. The interaction between Sup ODNs and conventional anticancer drugs was analyzed by isobologram analysis using CalcuSyn software (Biosoft, Cambridge, UK) to determine whether the combination was additive or synergistic; a combination index $(\mathrm{CI})<1.0$ indicated a synergistic effect.

\section{Results}

Effect of Sup ODNs on proliferation of A549 NSCLC cell line. A549 NSCLC cell line was cultured for 3 days with 0.1-30 $\mu \mathrm{M}$ Sup ODNs or control ODNs and evaluated for viability by MTT assay. There was a significant and dose-dependent reduction in viability of A549 cells treated with Sup ODNs when compared to control ODNs (Fig. 1A; p<0.05). The mean 50\% inhibitory concentration $\left(\mathrm{IC}_{50}\right)$ value for A549 cells was $2.5 \mu \mathrm{M}$. Normal human bronchial epithelial cells treated with high concentrations of Sup ODNs (10-30 $\mu \mathrm{M})$ showed no significant reduction 


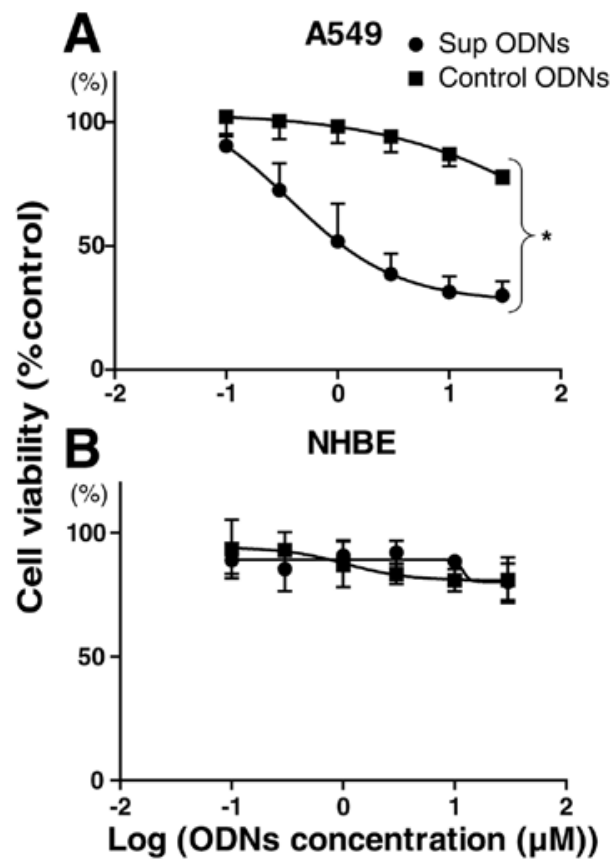

Figure 1. Antiproliferative effect of Sup ODNs on A549 NSCLC and NHBE cells. (A) A549 and (B) NHBE cells were treated with 0.1-30 $\mu$ M Sup ODNs or control ODNs for $72 \mathrm{~h}$. Cell viability was evaluated using the MTT assay. Results represent mean \pm SD change in cell viability from three independent experiments; ${ }^{*} \mathrm{p}<0.05$. in viability compared to those treated with control ODNs or medium alone (Fig. 1B).

Induction of G1 phase arrest via expression of $p 15^{I N K 4 b}$ and $p 27^{K I P I}$. A549 cells were incubated with $3 \mu \mathrm{M}$ Sup ODNs or control ODNs. The effect of this treatment on progression through the cell cycle was analyzed by flow cytometry (Fig. 2A). Sup ODNs treatment led to $\sim 20 \%$ increase in the number of cells in G0/G1 phase, whereas the frequency in S phase fell by $10-15 \%$ (Fig. 2B). These findings are consistent with Sup ODNs inducing cell cycle arrest in the G1 phase.

Expression of cell cycle-related proteins was then analyzed by western blot analysis. Results showed that Sup ODNs increased expression of Cdk inhibitors including $\mathrm{p} 15^{\mathrm{INK} 4 \mathrm{~b}}$ and $\mathrm{p} 27^{\mathrm{KIP} 1}$, therefore increased expression of cyclin $\mathrm{E}$ and reduced expression of $\mathrm{Cdk} 2$, cyclin D1 and retinoblastoma protein $(\mathrm{pRb})$ phosphorylation in a dose-dependent manner (Fig. 3A). As shown in Fig. 3B, these changes were found at significant level in cells treated with $3 \mu \mathrm{M}$ Sup ODNs for $24 \mathrm{~h}$ by densitometric analysis of band intensities. These results were similar to previous reports of induced G0/G1 arrest via Cdk inhibitors including p21 and p $27^{\mathrm{KIP} 1}(17,18)$. In contrast, Sup ODNs did not increase expression of p53 and p21. Reduction of pRb phosphorylation is a key factor of G1 phase cell cycle arrest $(19,20)$, therefore, these results demonstrated that Sup-ODN-mediated G1 phase of cell cycle arrest was achieved via the $\mathrm{p} 15^{\mathrm{INK} 4 \mathrm{~b}}$ and $\mathrm{p} 27^{\mathrm{KIP} 1} / \mathrm{pRb}$ pathway.

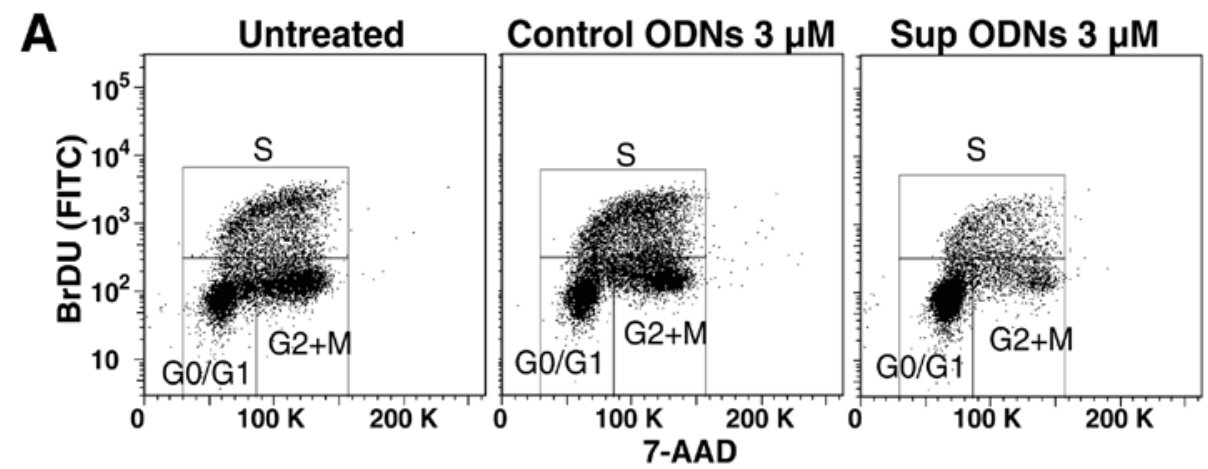

B

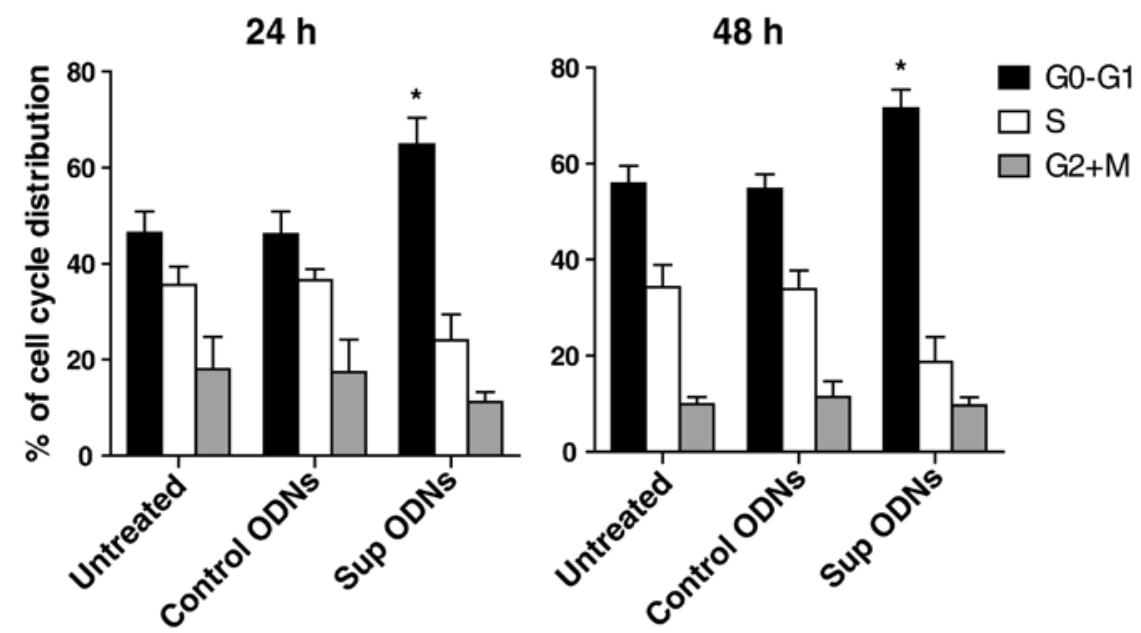

Figure 2. Effect of Sup ODNs on NSCLC cell cycle. A549 cells were treated with $3 \mu \mathrm{M}$ Sup ODNs or control ODNs from 24 to 48 h. Cells were stained with 7-AAD and treated with BrdU as described in Materials and methods section. (A) Representative data show the distribution of cells at each stage of the cell cycle determined by flow cytometric analysis. (B) Results show mean \pm SEM from four independent experiments, performed as described above. ${ }^{*}$ p $<0.05$ when compared to cultures treated with control ODNs. 


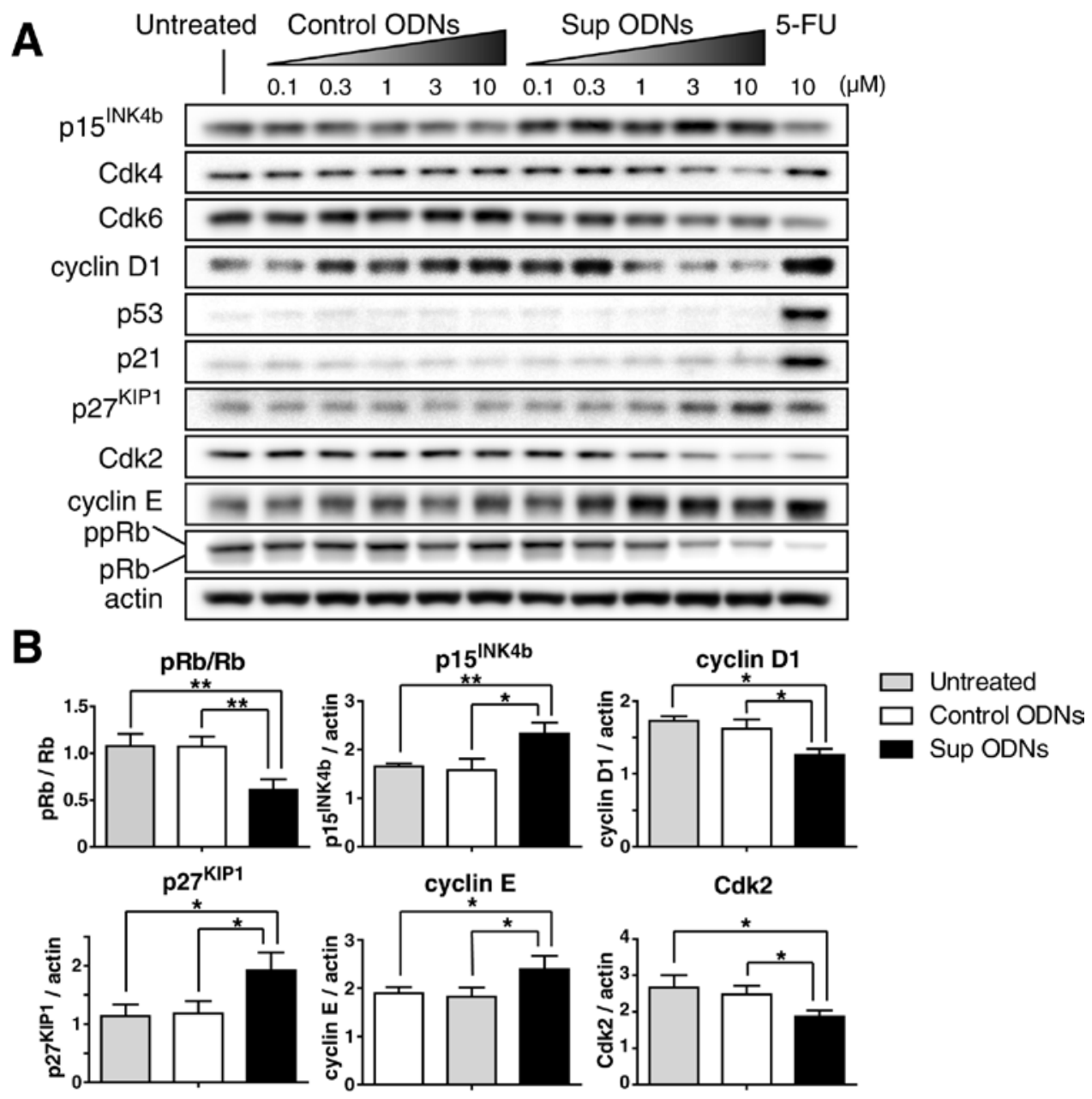

Figure 3. Effect of Sup ODNs on cell-cycle-related protein expression by A549 cells. (A) Expression of cell cycle-related protein was analyzed in A549 cells treated with $0.1,0.3,1,3,10 \mu \mathrm{M}$ Sup ODNs or control ODNs for $24 \mathrm{~h}$, by western blot analysis. A549 cells treated with 5-FU $10 \mu \mathrm{M}$ were used as a positive control of p53 and 21 (42). (B) Band intensities of A549 cells treated with/without $3 \mu \mathrm{M}$ Sup ODNs or control ODNs for $24 \mathrm{~h}$ were quantified by densitometric analysis. The band intensities were normalized to actin of the corresponding lane and the signal for pRB of each lane was normalized to total RB of the same lane. Results represent the mean \pm SD of three independent experiments. ${ }^{*} \mathrm{p}<0.05,{ }^{* *} \mathrm{p}<0.01$ when compared to cultures untreated or treated with control ODNs.

Effect of Sup ODNs on Akt and ERK1/2 phosphorylation. To clarify the mechanism of action of Sup ODNs, the screening was performed by using a Human Phospho-Kinase Antibody Array (R\&D Systems, Minneapolis, MN, USA). A549 cells was cultured for $16 \mathrm{~h}$ under serum-starved conditions and then treated with $3 \mu \mathrm{M}$ Sup ODNs, or untreated for $1 \mathrm{~h}$ in normal medium. The expression of phosphorylated Akt and ERK1/2 was increased on untreated cells. In contrast, Sup ODNs reduced the expression of them (data not shown).

Confirmation of the effect of Sup ODNs on Akt and ERKI/2 phosphorylation. A549 NSCLC cell line was cultured for $16 \mathrm{~h}$ under serum-starved conditions to dephosphorylate Akt and ERK1/2, and then treated with increasing concentrations $(0.1-30 \mu \mathrm{M})$ of Sup ODNs or control ODNs for up to $24 \mathrm{~h}$ in normal medium. Western blot analysis revealed that cells treated with $3 \mu \mathrm{M}$ Sup ODNs reduced Akt phosphorylation (at both Ser473 and Thy308) and ERK1/2 phosphorylation compared to those treated with $3 \mu \mathrm{M}$ control ODNs (Fig. 4A). The effect of Sup ODNs was confirmed by a dose-dependent reduction of Akt and ERK1/2 phosphorylation or $3 \mathrm{~h}$ after administration
(Fig. 4B and C). No such effect was observed in cells treated with control ODNs. Treatment with Sup ODNs tended to increase the level of expression of the tumor-suppressor gene $\mathrm{p} 15^{\mathrm{INK} 4 \mathrm{~b}}$ and p2 $7^{\text {KIP1 }}$, particularly at 18 and $24 \mathrm{~h}$ (Fig. 4A). From 12 to $24 \mathrm{~h}$, Sup ODNs reduced the expression of $\mathrm{pRb}$, which acts as control checkpoint for the G1 phase of the cell cycle (Fig. 4A). These findings suggest that G1 cell cycle arrest might be involved in the antiproliferative activity of Sup ODNs.

Effect of combining Sup ODNs with anticancer drugs. To examine whether Sup ODNs might interact synergistically with various drugs currently approved for the treatment of NSCLC patients, A549 NSCLC cell line was cultured with increasing concentrations of Sup ODNs plus other third-generation anticancer drugs (including 5-FU, gemcitabine, paclitaxel, VNR and irinotecan) or platinum-containing drugs (carboplatin and cisplatin) for $72 \mathrm{~h}$ and the subsequent assessment of their effects on cell viability by using the MTT assay. Combining results from multiple dose-response curves enabled us to calculate CI. The experiment used a variable-ratio drug combination design that enabled the magnitude of synergy (or antagonism) between 

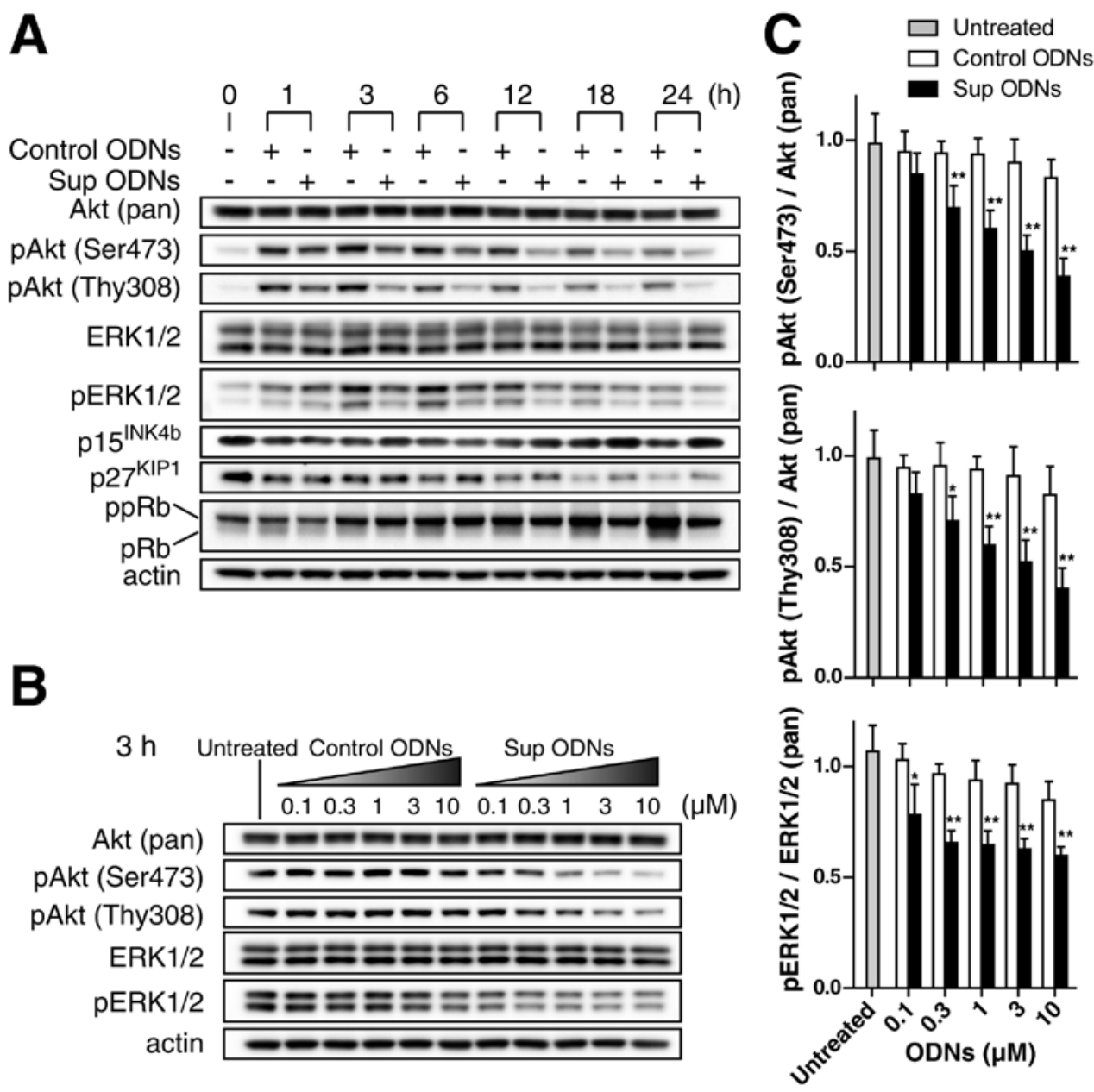

Figure 4. Effect of Sup ODNs on Akt and Erk1/2 phosphorylation by A549 cells. (A and B) Expression of phosphorylated Akt, phosphorylated ERK1/2, p15 ${ }^{\text {INK4b }}$, p2 $7^{\mathrm{KIP} 1}$ and pRB was analyzed in A549 cells treated with $3 \mu \mathrm{M}$ Sup ODNs or control ODNs for the indicated times, by western blot analysis. Actin was chosen as the loading control in all blots. Results are representative of at least three independent experiments. (C) Densitometric analysis of band intensity representing the mean \pm SD of three independent experiments. ${ }^{*} \mathrm{p}<0.05,{ }^{* *} \mathrm{p}<0.01$ when compared to cultures treated with control ODNs.

Table I. CI for A549 NSCLC cell line.

\section{Anticancer drug}

\begin{tabular}{ll}
\hline 5-Fluorouracil & $0.43 \pm 0.25$ \\
Gemcitabine & $0.78 \pm 0.19$ \\
Paclitaxel & $0.54 \pm 0.37$ \\
Vinorelbine & $0.46 \pm 0.27$ \\
Irinotecan & $0.51 \pm 0.09$ \\
Carboplatin & $0.94 \pm 0.11$ \\
Cisplatin & $0.86 \pm 0.06$ \\
\hline
\end{tabular}

CI, combination index; ED, median effective dose.

agents to be calculated independently for each data point. Table I shows that the mean CI value for each of the combinations, except the platinum-containing drugs, ranged from 0.43 to 0.78 , indicating that adding Sup ODNs to third-generation conventional anticancer drugs synergistically (defined by $\mathrm{CI}$ $<1.0)$ reduced the proliferation of A549 cells. Of these, 5-FU and VNR showed favorable outcomes when combined with
Sup ODNs, therefore, we further analyzed the combination effects by using these drugs. Increasing amounts of Sup ODN plus 5-FU reduced cell viability in a dose-dependent manner (Fig. 5A). Combining results from multiple dose-response curves and normalized isobolograms based on the method of Chou and Talalay are shown in Fig. $5 B$ and $C(21,22)$. In the normalized isobologram, experimental data points, represented by dots located below, on or above the diagonal line, indicate synergism, additivity and antagonism, respectively. As shown in Fig. 5B and C, results from combining treatment of Sup ODNs plus 5-FU indicated a favorable outcome for synergism.

Synergistic induction of apoptosis by Sup ODNs plus anticancer drug. A549 NSCLC cell line was cultured with/without $3 \mu \mathrm{M}$ Sup ODNs or control ODNs in the presence or absence of $10 \mathrm{nM}$ VNR from 24 to $48 \mathrm{~h}$. Apoptotic cells were detected by flow cytometric analysis. Sup ODNs treatment induced apoptosis in comparison with non-treatment or control ODNs treatment. Moreover, VNR plus Sup ODNs treatment led to increased apoptotic cells synergistically (Fig. 6A and B). Western blot analysis revealed that Sup ODNs increase cleaved caspase-3, cleaved poly ADP ribose polymerase (PARP) and 

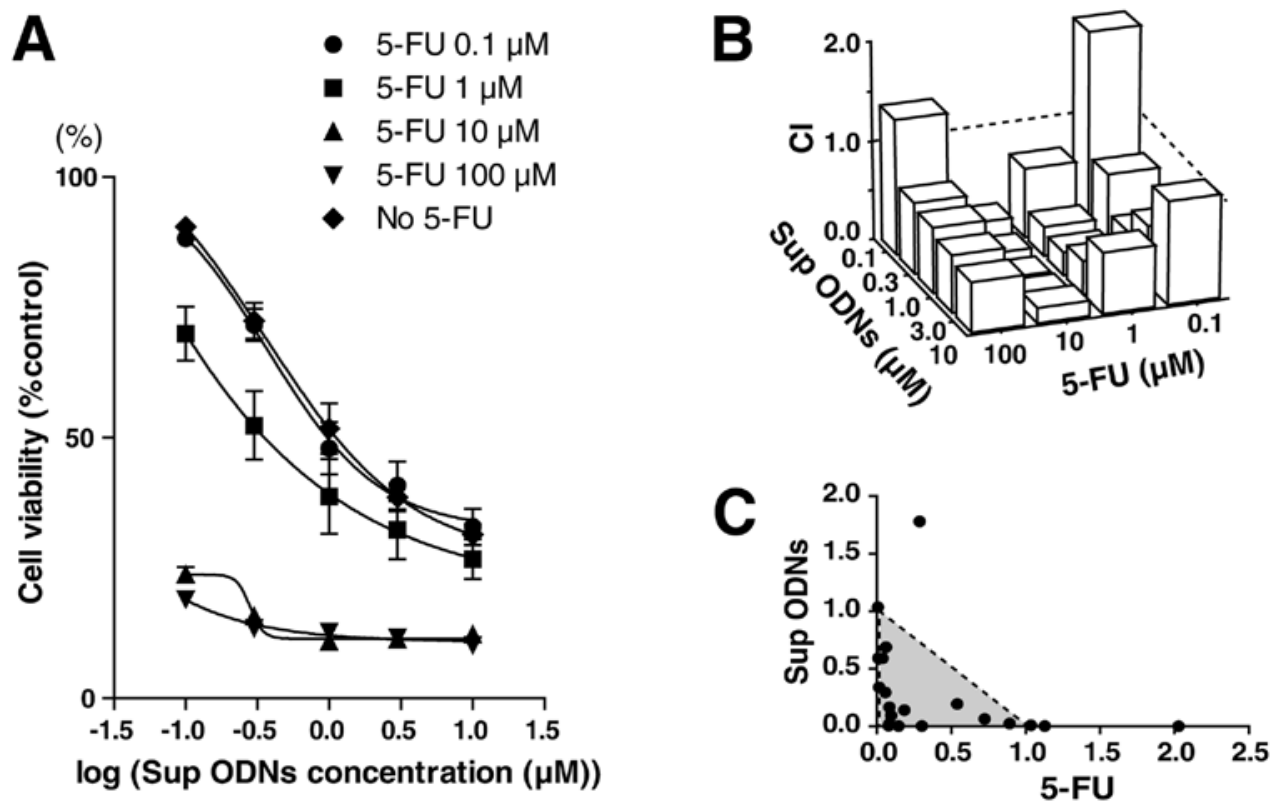

Figure 5. Effect of treating A549 cells with 5-FU plus Sup ODNs. (A) A549 cells were incubated with Sup ODNs for $1 \mathrm{~h}$. 5-FU was added for $72 \mathrm{~h}$ of culture. The effect of each treatment on cell proliferation was evaluated using the MTT assay. (B) The CI for 5-FU plus Sup ODNs at various concentrations of each agent is shown. (C) Normalized isobologram for 5-FU plus Sup ODNs. Experimental data points, represented by dots located below (the shaded area), on or above the dotted line, indicate synergism, additivity and antagonism, respectively. The CI was calculated using the index-isobologram method based on the median principle developed by Chou and Talalay $(21,22) . \mathrm{CI}<1$ is indicative of synergy.

A

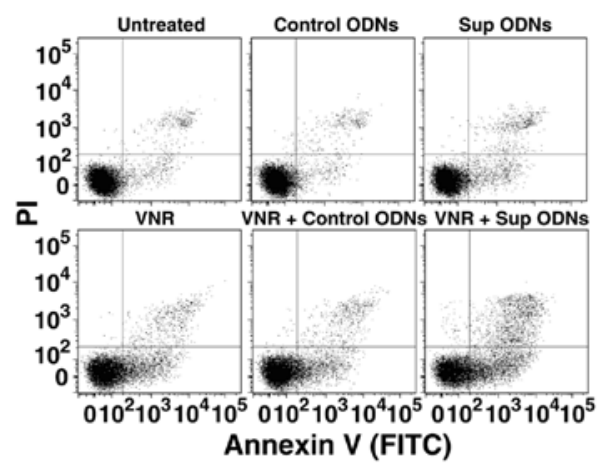

C

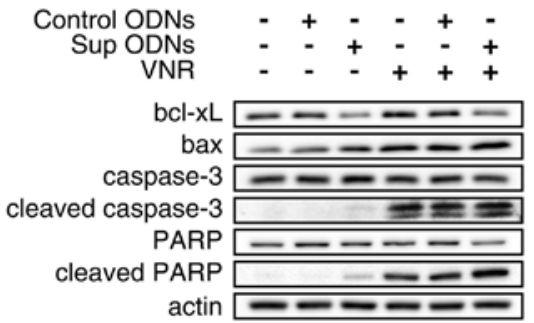

B

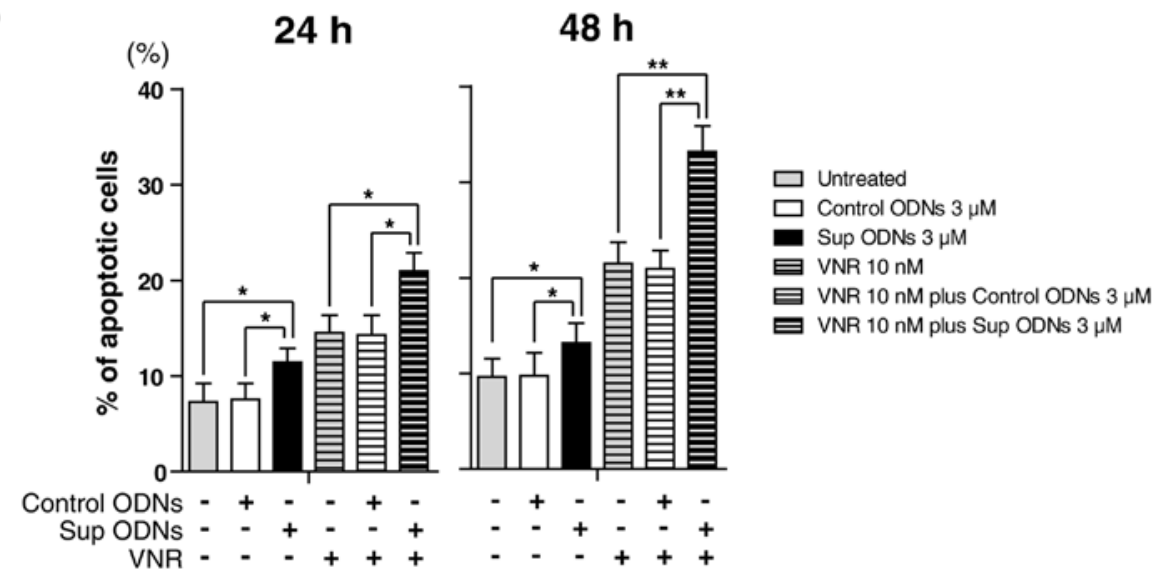

Figure 6. Effect of Sup ODNs on induction of apoptosis by A549 cells. (A) A549 cells were treated with/without $3 \mu$ M Sup ODNs or control ODNs in the presence or absence of $10 \mathrm{nM}$ VNR from 24 to $48 \mathrm{~h}$. Cells were stained with FITC conjugated Annexin V and PI. Data show the distribution of apoptotic cells determined by flow cytometric analysis. (B) Results show percentage of apoptotic cells and expressed as mean \pm SD from three independent experiments, performed as described above. ${ }^{*} \mathrm{p}<0.05,{ }^{* *} \mathrm{p}<0.01$ when compared to cultures untreated or treated with control ODNs and in combination with VNR compared to cultures treated with VNR alone or VNR plus control ODNs. (C) Expression of bcl-xL, bax, cleaved caspase-3 and cleaved PARP was analyzed in A549 cells treated with/without $3 \mu$ M Sup ODNs or control ODNs in the presence or absence of $10 \mathrm{nM}$ VNR for $48 \mathrm{~h}$ by western blot analysis. Actin was chosen as the loading control in all blots. Results are representative of at least three independent experiments. 
bax, and decrease bcl-xL that acts as pro-survival protein by inhibiting its apoptotic effect (Fig. 6C).

\section{Discussion}

This study demonstrated that Sup ODNs inhibited A549 cell proliferation by reducing Akt and Erk1/2 phosphorylation and then increasing expression of cyclin-dependent kinase inhibitors ( $\mathrm{p} 15^{\mathrm{INK} 4 \mathrm{~b}}$ and $\left.\mathrm{p} 27^{\mathrm{KIP} 1}\right)$, and increased sensitivity of cells to conventional anticancer drugs.

Sup ODNs inhibit inflammatory responses and prevent the development of inflammation-dependent cancer $(9-11,14,15)$. However, the current work is believed to be the first to document that Sup ODNs have a direct antiproliferative effect on cancer cell line. Studies involving ODNs with suppressive activity (but a different sequence than Sup ODNs) have reported that ODNs and plasmids containing telomere-derived TTAGGG sequence motifs induce apoptosis and cellular senescence via the ataxia-telangiectasia mutated (ATM) gene-p53-p21 and p16 ${ }^{\mathrm{INK} 4 \mathrm{a}}-\mathrm{pRb}$ pathways in malignant cells (23-26). Current results examine the antiproliferative effects of Sup ODNs on A549 NSCLC cell line (p16 ${ }^{\text {INK4a }}$-null but wild-type p53). Our results revealed that Sup ODNs did not increase the expression of p53 and p21 (Fig. 3A). Thus, our data suggest that Sup ODNs induce $\mathrm{G} 1$ cell cycle arrest via different pathways.

The western blot analysis results shown in Fig. 3 indicate that Sup ODNs increased accumulation of $\mathrm{p} 15^{\mathrm{INK} 4 \mathrm{~b}}$ and $\mathrm{p} 27^{\mathrm{KIP} 1}$, consistent with G1 cell cycle arrest, loss of hypophosphorylated $\mathrm{pRb}$, and increased unphosphorylated pRb (Figs. 3 and 4). The INK4 kinase inhibitors (p15 ${ }^{\text {INK4b }}, \mathrm{p} 16^{\text {INK4a }}, \mathrm{p} 18^{\text {INK4c }}$ and $\mathrm{p} 19^{\text {INK4d }}$ ) negatively regulate cyclin D1, D2 and D3 complexes that bind Cdk4/Cdk6 and phosphorylate pRb (19). Many human malignancies are characterized by inactivation of $\mathrm{p} 16^{\text {INK4a }}$ or $\mathrm{pRb}$, or the amplification of cyclin D1 or Cdk4 (27). The A549 cell line used in the present work was null for $\mathrm{p} 16^{\mathrm{INK} 4 \mathrm{a}}$ but wild-type for pRb. p21 and p $27^{\mathrm{KIP} 1}$ is a member of the Cip/Kip family of cyclin-dependent kinase inhibitors. These proteins inhibit kinase activities of pre-activated G1 cyclin E-Cdk2 and other cyclins (28). pRb exists in three general forms: unphosphorylated, hypophosphorylated and hyperphosphorylated. Freshly synthesized $\mathrm{pRb}$ is unphosphorylated and is present during the G0 phase of the cell cycle. Hypophosphorylated pRb is present in contact-inhibited cells during early G1. Hyperphosphorylated $\mathrm{pRb}$ is inactive and is present in the late $\mathrm{G} 1, \mathrm{~S}, \mathrm{G} 2$ and $\mathrm{M}$ phases of the cell cycle (29). These findings suggest that Sup ODNs induce $\mathrm{G} 1$ cell cycle arrest via the $\mathrm{p} 15^{\mathrm{INK} 4 \mathrm{~b}}$ and $\mathrm{p} 27^{\mathrm{KIP} 1} / \mathrm{pRb}$ pathway rather than senescence via the ATM-p53-p21 or p16 ${ }^{\text {INK4a }}$-pRb pathways.

We found that Sup ODNs decreased the activated form of Akt and ERK1/2 as a mechanism of increasing the expression of p15 INK4b and $\mathrm{p} 27^{\mathrm{KIP} 1}$ on A549 cells. As shown in Fig. 4, the addition of Sup ODNs to cultured NSCLC cells decreased their accumulation of the activated form of the serine/threonine protein kinase Akt and ERK1/2 in a dose-dependent manner. Activated Akt phosphorylates a variety of proteins involved in critical cellular processes, including proliferation and survival (30,31). Moreover, the activated form of Akt has been linked to tumorigenesis and drug resistance in cancer cells, and correlates with poor prognosis in NSCLC $(4,30,31)$. Similarly ERK signaling also promotes cell proliferation, cell survival and metastasis. This pathway is aberrantly activated in cancer, and the ERK pathways have attracted intense research interests $(6,32)$. Thus, these findings suggest that Sup ODNs may be of value in the therapy of lung cancer.

Although treatment with Sup ODNs as a stand-alone agent may slow the growth of A549 NSCLC cell line, chemotherapy of patients with advanced disease typically includes multiple agents (33). Recent reports document that agents with specific molecular targets can be combined with conventional anticancer drugs to improve treatment of patients with advanced NSCLC $(34,35)$. Thus, the potential benefit of administering Sup ODNs in combination with anticancer drugs was evaluated. As seen in Fig. 5 and Table I, Sup ODNs were found to synergize with several third-generation anticancer drugs, but not with platinumcontaining drugs.

In general, agents that target microtubules (such as paclitaxel and VNR) block cell growth by inhibiting mitosis, whereas topoisomerase inhibitors (such as irinotecan) and antimetabolites (such as 5-FU and gemcitabine) are characterized by S-phase-specific cytotoxicity and induce apoptosis and G1 cell cycle arrest $(36,37)$. Although Sup ODNs also induced G1 cell cycle arrest (Figs. 2 and 3), their activity was synergistic when combined with topoisomerase inhibitors and anti-metabolites (Table I). There are two possible explanations for this. First, topoisomerase inhibitors and antimetabolites cause DNA damage and then induce G1 cell cycle arrest via the ATM/p53/p21 pathway. This differs from the effect of Sup ODNs, which blocks the $\mathrm{p} 15^{\mathrm{INK} 4 \mathrm{~b}}$ and $\mathrm{p} 27^{\mathrm{KIP} 1} / \mathrm{pRb}$ pathway (Figs. 3 and 4 ). Second, Akt inhibits cell death pathways by directly phosphorylating and inactivating proteins involved in apoptosis (38). As seen in Figs. 4 and 6, Sup ODNs decreased the activated form of Akt (phosphorylated Akt), and decreased expression of pro-survival protein (such as bcl-xL), leading to induce apoptosis. Moreover, Sup ODNs synergistically enhanced apoptosis when combined with other agents including VNR (Fig. 6).

The anticancer effect of platinum-containing drugs depends on the ability to bind covalently to DNA and subsequently to modify the structure of the DNA. Such covalent interactions result in crosslinks between adjacent nucleobases that block DNA replication and transcription, and ultimately, cell division (39). It is well known that platinum-containing drugs form preferably covalent bonds to the $\mathrm{AG}$ and $\mathrm{GG}$ sequences of DNA and ODNs $(40,41)$. Therefore, we assume that cisplatin and carboplatin bound to Sup ODNs, which led to inhibition of effective delivery of Sup ODNs to target lesions, and thus resulting in no significant synergism for combination of platinum-containing drugs and Sup ODNs.

In conclusion, our results are believed to be the first to demonstrate that Sup ODNs have a direct anticancer effect, and increase the sensitivity of A549 NSCLC cells to conventional anticancer drugs by modifying the Akt and ERK1/2 pathway. Thus, Sup ODNs may become a novel therapeutic strategy for NSCLC patients. Studies to elucidate further the efficacy of Sup ODNs in animal models of lung cancer are planned.

\section{Acknowledgements}

This study was supported in part by grants (nos. 21790778 and 23790917 to T.S.) from the Ministry of Education, Culture, Sports, Science and Technology of Japan. The authors thank 
Drs Naoki Miyazawa and Ryusuke Yoshimi (Department of Internal Medicine and Clinical Immunology, Yokohama City University Graduate School of Medicine) for helpful discussions and skillful technical assistance.

\section{References}

1. Jemal A, Bray F, Center MM, Ferlay J, Ward E and Forman D Global cancer statistics. CA Cancer J Clin 61: 69-90, 2011.

2. Sandler AB, Nemunaitis J, Denham C, et al: Phase III trial of gemcitabine plus cisplatin versus cisplatin alone in patients with locally advanced or metastatic non-small-cell lung cancer. J Clin Oncol 18: 122-130, 2000

3. Giancotti FG and Ruoslahti E: Integrin signaling. Science 285: $1028-1032,1999$.

4. Okamura M, Yamaji S, Nagashima Y, et al: Prognostic value of integrin beta1-ILK-pAkt signaling pathway in non-small cell lung cancer. Hum Pathol 38: 1081-1091, 2007.

5. Vicent S, Lopez-Picazo JM, Toledo G, et al: ERK1/2 is activated in non-small-cell lung cancer and associated with advanced tumours. Br J Cancer 90: 1047-1052, 2004.

6. Roberts PJ and Der CJ: Targeting the Raf-MEK-ERK mitogenactivated protein kinase cascade for the treatment of cancer Oncogene 26: 3291-3310, 2007.

7. Balkwill $\mathrm{F}$ and Mantovani A: Inflammation and cancer: back to Virchow? Lancet 357: 539-545, 2001.

8. Coussens LM and Werb Z: Inflammation and cancer. Nature 420: 860-867, 2002

9. Dong L, Ito S, Ishii KJ and Klinman DM: Suppressive oligonucleotides protect against collagen-induced arthritis in mice. Arthritis Rheum 50: 1686-1689, 2004.

10. Ikeuchi H, Kinjo T and Klinman DM: Effect of suppressive oligodeoxynucleotides on the development of inflammationinduced papillomas. Cancer Prev Res (Phila) 4: 752-757, 2011.

11. Zeuner RA, Ishii KJ, Lizak MJ, et al: Reduction of CpG-induced arthritis by suppressive oligodeoxynucleotides. Arthritis Rheum 46: 2219-2224, 2002.

12. Zeuner RA, Verthelyi D, Gursel M, Ishii KJ and Klinman DM: Influence of stimulatory and suppressive DNA motifs on host susceptibility to inflammatory arthritis. Arthritis Rheum 48 1701-1707, 2003

13. Shirota H, Gursel M and Klinman DM: Suppressive oligodeoxynucleotides inhibit Th1 differentiation by blocking IFN-gamma- and IL-12-mediated signaling. J Immunol 173 : 5002-5007, 2004.

14. Shirota H, Gursel I, Gursel M and Klinman DM: Suppressive oligodeoxynucleotides protect mice from lethal endotoxic shock. J Immunol 174: 4579-4583, 2005.

15. Sato T, Shimosato T, Alvord WG and Klinman DM: Suppressive oligodeoxynucleotides inhibit silica-induced pulmonary inflammation. J Immunol 180: 7648-7654, 2008.

16. Gursel I, Gursel M, Yamada H, Ishii KJ, Takeshita F and Klinman DM: Repetitive elements in mammalian telomeres suppress bacterial DNA-induced immune activation. J Immunol 171: 1393-1400, 2003

17. Park KH, Seol JY, Yoo CG, et al: Adenovirus expressing p27(Kip1) induces growth arrest of lung cancer cell lines and suppresses the growth of established lung cancer xenografts. Lung Cancer 31: 149-155, 2001.

18. Sandor V, Senderowicz A, Mertins S, et al: P21-dependent g(1) arrest with downregulation of cyclin D1 and upregulation of cyclin E by the histone deacetylase inhibitor FR901228. Br J Cancer 83: 817-825, 2000

19. Weinberg RA: The retinoblastoma protein and cell cycle control. Cell 81: 323-330, 1995.

20. Sherr CJ and Roberts JM: CDK inhibitors: positive and negative regulators of G1-phase progression. Genes Dev 13: 1501-1512, 1999.

21. Chou TC and Talalay P: Quantitative analysis of dose-effect relationships: the combined effects of multiple drugs or enzyme inhibitors. Adv Enzyme Regul 22: 27-55, 1984.
22. Chou TC, Motzer RJ, Tong Y and Bosl GJ: Computerized quantitation of synergism and antagonism of taxol, topotecan, and cisplatin against human teratocarcinoma cell growth: a rational approach to clinical protocol design. J Natl Cancer Inst 86: 1517-1524, 1994

23. Li GZ, Eller MS, Hanna K and Gilchrest BA: Signaling pathway requirements for induction of senescence by telomere homolog oligonucleotides. Exp Cell Res 301: 189-200, 2004

24. Yaar M, Eller MS, Panova I, et al: Telomeric DNA induces apoptosis and senescence of human breast carcinoma cells. Breast Cancer Res 9: R13, 2007.

25. Longe HO, Romesser PB, Rankin AM, et al: Telomere homolog oligonucleotides induce apoptosis in malignant but not in normal lymphoid cells: mechanism and therapeutic potential. Int J Cancer 124: 473-482, 2009.

26. Guo XF and Cao EH: Telomeric plasmid induces human cancer cell dysfunction depending on ATM activity. Cell Biochem Funct 28: 381-386, 2010.

27. Hall M and Peters G: Genetic alterations of cyclins, cyclindependent kinases, and Cdk inhibitors in human cancer. Adv Cancer Res 68: 67-108, 1996.

28. Toyoshima $\mathrm{H}$ and Hunter T: p27, a novel inhibitor of G1 cyclin-Cdk protein kinase activity, is related to $\mathrm{p} 21$. Cell 78: 67-74, 1994.

29. DeCaprio JA, Ludlow JW, Lynch D, et al: The product of the retinoblastoma susceptibility gene has properties of a cell cycle regulatory element. Cell 58: 1085-1095, 1989.

30. Vivanco I and Sawyers CL: The phosphatidylinositol 3-Kinase AKT pathway in human cancer. Nat Rev Cancer 2: 489-501, 2002.

31. Engelman JA: Targeting PI3K signalling in cancer: opportunities, challenges and limitations. Nat Rev Cancer 9: 550-562, 2009.

32. Montagut $\mathrm{C}$ and Settleman J: Targeting the RAF-MEK-ERK pathway in cancer therapy. Cancer Lett 283: 125-134, 2009.

33. Pujol JL, Barlesi F and Daures JP: Should chemotherapy combinations for advanced non-small cell lung cancer be platinum-based? A meta-analysis of phase III randomized trials. Lung Cancer 51: 335-345, 2006.

34. Reck M, von Pawel J, Zatloukal P, et al: Phase III trial of cisplatin plus gemcitabine with either placebo or bevacizumab as first-line therapy for nonsquamous non-small-cell lung cancer: AVAil. J Clin Oncol 27: 1227-1234, 2009.

35. Sandler A, Gray R, Perry MC, et al: Paclitaxel-carboplatin alone or with bevacizumab for non-small-cell lung cancer. $\mathrm{N}$ Engl J Med 355: 2542-2550, 2006.

36. Liu LF, Desai SD, Li TK, Mao Y, Sun M and Sim SP: Mechanism of action of camptothecin. Ann NY Acad Sci 922: 1-10, 2000.

37. Longley DB, Harkin DP and Johnston PG: 5-fluorouracil mechanisms of action and clinical strategies. Nat Rev Cancer 3: 330-338, 2003.

38. Madrid LV, Wang CY, Guttridge DC, Schottelius AJ, Baldwin AS Jr and Mayo MW: Akt suppresses apoptosis by stimulating the transactivation potential of the RelA/p65 subunit of NF-kappaB. Mol Cell Biol 20: 1626-1638, 2000.

39. Zaludova R, Zakovska A, Kasparkova J, et al: DNA interactions of bifunctional dinuclear platinum(II) antitumor agents. Eur J Biochem 246: 508-517, 1997.

40. Reeder F, Guo Z, Murdoch PD, et al: Platination of a GG site on single-stranded and double-stranded forms of a 14-base oligonucleotide with diaqua cisplatin followed by NMR and HPLC - influence of the platinum ligands and base sequence on 5'-G versus 3'-G platination selectivity. Eur J Biochem 249: 370-382, 1997

41. Blommaert FA, van Dijk-Knijnenburg HC, Dijt FJ, et al: Formation of DNA adducts by the anticancer drug carboplatin: different nucleotide sequence preferences in vitro and in cells. Biochemistry 34: 8474-8480, 1995

42. Van Triest B,Pinedo HM, Giaccone G and Peters GJ: Downstream molecular determinants of response to 5-fluorouracil and antifolate thymidylate synthase inhibitors. Ann Oncol 11: 385-391, 2000 . 